\title{
PENGARUH KUALITAS PRODUK, PROMOSI PENJUALAN, DAN LOKASI GERAI TERHADAP KEPUTUSAN PEMBELIAN KONSUMEN TAS EIGER DI KOTA BOGOR
}

\author{
Oleh : \\ Heruwansyah \\ E-mail : heruwansyah999@gmail.com
}

\begin{abstract}
This study aims to examine the effect of Product Quality, Sales Promotion, and Outlet Location on Consumer Purchasing Decisions on Eiger Brand Bags in Bogor City. This study uses independent variables namely Product Quality, Sales Promotion, Outlet Location. The dependent variable is Consumer Purchase Decision. The data in this study are secondary data.

The sample of this study is consumers who have already bought the Eiger brand bag products. The sample is done by non probability sampling method. Data collection was conducted with a questionnaire distributed directly to consumers who had bought Eiger brand bags as many as 120 respondents. The statistical method uses multiple linear regression analysis, by testing the statistical test hypothesis $t$.

The results of this study indicate a positive and significant variable in Product Quality with $t$ count greater than $t$ table (3.674> 1.66), sales promotion $t$ count greater than $t$ table $(2.526>1.66)$, and there is one variable that is not positive and significant effect on Consumer Purchasing Decisions namely Outlet Location variables with the acquisition of $t$ count smaller than $t$ table $(0.65<1.66)$.

Keywords: Product Quality, Sales Promotion, Outlet Location, Consumer Purchase Decision.
\end{abstract}




\section{PENDAHULUAN}

Pada zaman sekarang ini fashion sudah menjadi bagian dari kebutuhan, di mana setiap insan perlu memiliki khsusnya tas dipergunakan untuk keperluan membawa barang dalam bepergian, dalam keputusan pembelian suatu produk saat ini sangat dipengaruhi berbagai faktor lainnya seperti kualitas, harga, daya tahan, dan kegunaan suatu produk maupun faktor dari luar seperti: promosi penjualan, dan lokasi gerai. Selain itu saat ini konsumen semakin cerdas dalam memilih suatu produk tertentu sesuai dengan kebutuhan yang mereka perlukan, banyak sekali faktor yang menentukan keputusan pembelian konsumen ini terhadap merek yang banyak beredar di pasar (Setiawan, B., 2010).

Salah satu pertimbangan konsumen dalam memutuskan pembelian suatu produk adalah kualitas produk yang dapat memenuhi keinginan konsumen, bila tidak sesuai dengan spesifikasi maka produk akan ditolak, sekalipun produk tersebut masih dalam batas toleransi yang telah ditentukan maka produk tersebut seharusnya menjadi catatan untuk menghindari terjadinya kesalahan yang lebih besar diwaktu yang akan datang, kondisi konsumen yang semakin kritis dalam hal kualitas juga memaksa perusahaan untuk dapat mempertahankan dan meningkatan mutu produknya agar terhindar dari klaim dan ketidakpuasan serta agar dapat bersaing dengan perusahaan lain yang sejenis.

Keputusan konsumen untuk membeli ataupun tidak terhadap suatu produk merupakan suatu tantangan dan masalah yang dihadapi oleh PT Eigerindo Multi Produk Industri. Hal tersebut menyangkut keberlangsungan usaha yang dijalankan, sehingga mendorong pengelola untuk dapat meningkatkan strategi pemasaran dan mengamati perilaku konsumennya agar nantinya konsumen mendapatkan pelayanan yang baik dan muncul kepercayaan dalam diri konsumen terhadap produk Tas Merek Eiger. Memahami perilaku konsumen memang bukanlah perkara mudah, terlebih lagi setiap konsumen memiliki berbagai macam selera, harapan mengenai produk yang akan dibeli, kualitas produk, dan lokasi toko hingga pada akhirnya melakukan suatu keputusan pembelian (Meliana, S., \& Setiawan, B., 2013). 
Dengan promosi perusahaan dapat mengkomunikasikan produk kepada konsumen. Keunggulan-keunggulan dari produk dapat diketahui oleh konsumen dan dapat menarik konsumen untuk mencoba dan kemudian mengambil keputusan untuk membeli produk tersebut. Jadi promosi merupakan salah satu aspek yang penting dalam manajemen pemasaran karena dengan promosi, konsumen yang semula tidak tertarik terhadap produk dapat berubah fikiran untuk membeli produk.

Perusahaan menggunakan promosi untuk memicu transaksi, sehingga konsumen mau membeli suatu merek tertentu serta mendorong tenaga penjualan untuk secara agresif menjualnya (Setiawan, B., \& Rabuani, C., 2019). Selain itu promosi mampu merangsang permintaan akan suatu produk. Dengan promosi tersebut diharapkan konsumen mau membeli produk tersebut dan mendorong konsumen yang telah membeli agar membeli produk lebih sering lagi, sehingga akan terjadi pembelian ulang dan volume penjualan produk suatu perusahaan akan meningkat.

Suatu perusahaan dalam mengeluarkan produk sebaiknya disesuaikan dengan kebutuhan dan keinginan konsumen. Dengan begitu maka produk dapat bersaing di pasaran, sehingga menjadikan konsumen memiliki banyak alternatif pilihan produk sebelum mengambil keputusan untuk membeli suatu produk yang ditawarkan. Penentuan lokasi adalah strategi utama dalam usaha ritel. Lokasi yang strategis akan menjadi jalan pembuka yang menentukan kesuksesan sebuah usaha ritel. Penentuan lokasi toko ritel merupakan salah satu keputusan yang sangat signifikan dalam pemasaran ritel (retail marketing), dikarenakan toko ritel berbasis toko, lokasi yang strategis merupakan elemen kunci dalam menarik pelanggan untuk datang ke suatu outlet dan kadang-kadang dapat mengimbangi strategi bauran toko retail. Hal inilah yang menjadikan peran promosi dan lokasi penting untuk perusahaan dalam menjalankan bisnisnya (Setiawan, B., 2018).

Sekarang ini persaingan produk semakin ketat dikarenakan mulai bermunculan perusahaan produk tas yang sejenis yang ada di Kota Bogor. Kualitas, promosi, dan lokasi sangat berpengaruh terhadap keputusan pembelian konsumen, terbukti melalui wawancara singkat terhadap 30 responden. 


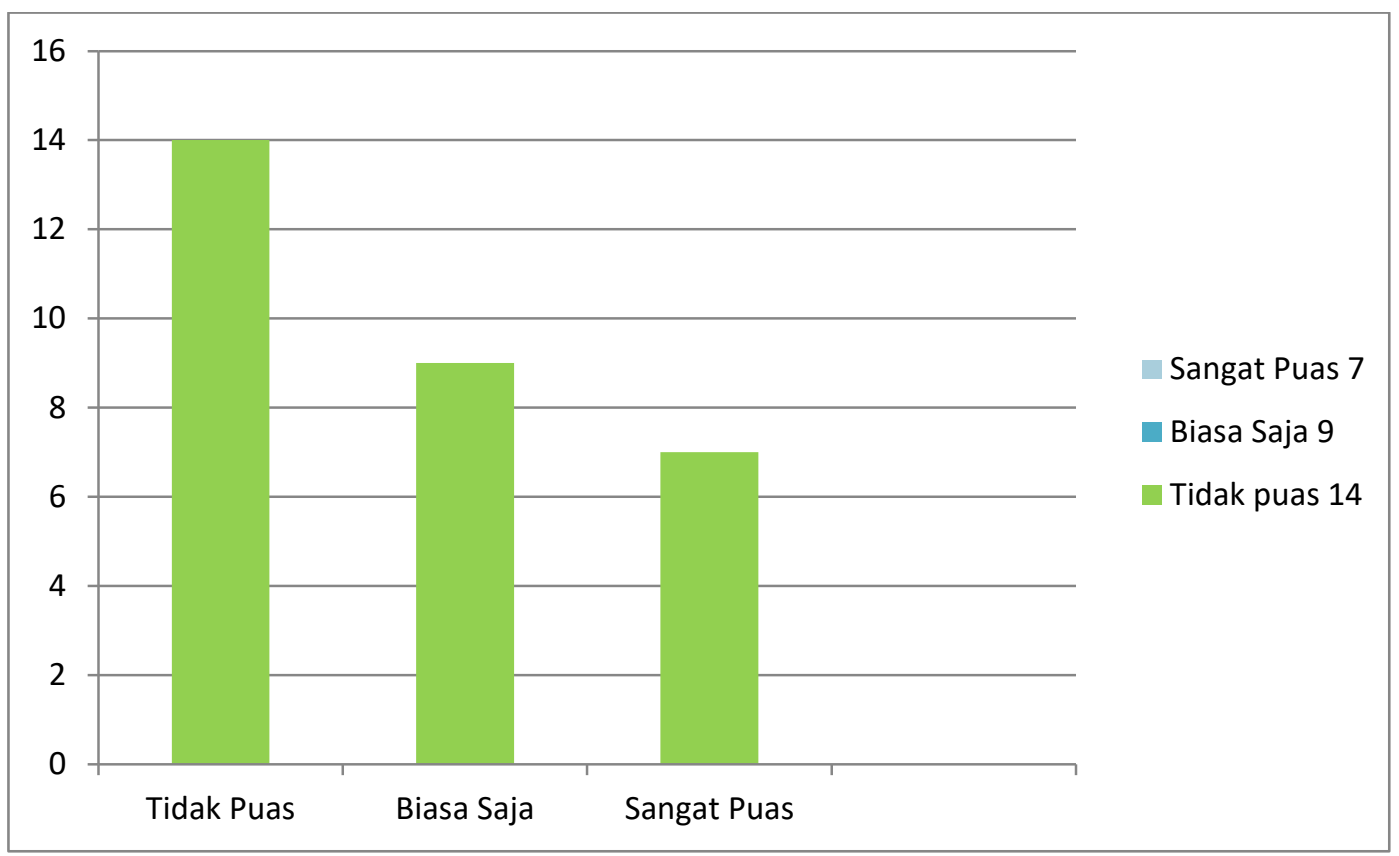

Grafik Keputusan Pembelian Konsumen Tas Merek Eiger di Kota Bogor

Sumber: Hasil Peneliti 2018

Dari grafik tersebut dapat disimpulkan bahwa keputusan pembelian terhadap Tas Merek Eiger: Tidak puas 14 orang, biasa saja 9 orang, dan sangat puas 7 orang. Berdasarkan grafik diatas masih banyak pelanggan Eiger yang tidak puas terhadap kualitas tas Eiger, konsumen menyampaikan bahwa kualitas yang dijual Eiger tidak sesuai dengan harga yang mereka beli, dan promosi yang dilakukan Eiger sangat jarang dilakukan jika dibanding dengan kompetitornya yaitu merek Consina.

Dari latar belakang masalah diatas, penulis tertarik untuk mengadakan penelitian dengan judul: "Pengaruh Kualitas Produk, Promosi Penjualan, Lokasi Gerai Terhadap Keputusan Pembelian Konsumen"

\section{TINJAUAN PUSTAKA}

Menurut Berkowitz, et., al (2012), mengemukakan bahwa keputusan pembelian merupakan tahap-tahap yang dilalui pembeli dalam menentukan pilihan tentang produk dan jasa yang hendak dibeli. 
Menurut Fandy Tjiptono (2008), kualitas produk merupakan perpaduan antara sifat dan karakteristik yang menentukan sejauh mana keluaran dapat memenuhi prasyarat kebutuhan pelanggan atau menilai sampai seberapa jauh sifat dan karakteristik itu memenuhi kebutuhannya, kualitas produk mempunyai delapan faktor yaitu Performance (kinerja), Durability (daya tahan), Conformance to specifications (kesesuaian dengan spesifikasi), Features (fitur), Reliability (reliabilitas), Aesthetics (estetika), Perceivedquality (kesan kualitas), dan Serviceability (kemampuan layanan).

Menurut Fandy Tjiptono (2008), mendefinisikan promosi penjualan adalah suatu bentuk komunikasi pemasaran yang bermaksud menyebarkan informasi, mempengaruhi/membujuk, dan mengingatkan pasar sasaran atas perusahaan dan produknya agar bersedia menerima, membeli dan loyal pada produk yang ditawarkan perusahaan yang bersangkutan.

Menurut Buchari (2008), mengemukakan bahwa lokasi adalah tempat perusahaan beroperasi atau tempat perusahaan melakukan kegiatan untuk menghasilkan barang dan jasa yang mementingkan segi ekonominya.

\section{METODE PENELITIAN}

Jenis data yang digunakan dalam penelitian ini adalah data kuantitatif dan kualitatif. Data kuantitatif adalah data yang berwujud angka-angka. Misalnya umur responden dan penghasilan, pendapatan pelanggan dan lainnya. Data kualitatif yaitu data yang berhubungan dengan kategori, karakteristik berwujud pernyataan atau berupa kata-kata. Data kualitatif dapat diangkakan dalam bentuk ordinal atau rangking. Data kualitatif ini diperoleh dari hasil pernyataanpernyataan yang di isi dalam kuesioner (Setiawan, B., 2015).

Data yang digunakan dalam penelitian ini terdiri dari atas data primer dan data sekunder. Menurut Sugiyono (2015) mendefinisikan data primer adalah "Sumber data yang langsung memberikan data kepada pengumpul data." Pengumpulan data primer dalam penelitian ini dengan cara menyebarkan kuesioner dan melakukan wawancara secara langsung dengan pihak-pihak yang berhubungan dengan penelitian yang dilakukan, yaitu pada semua orang di Kota Bogor yang sudah menggunakan Tas Merek Eiger. 
Menurut Sugiyono, (2014) data sekunder yaitu sumber data penelitian yang diperoleh peneliti secara tidak langsung melalui media perantara (diperoleh dan dicatat oleh pihak lain). Dalam penelitian ini, data sekunder bersumber dari jurnal dan artikel yang di ambil dari internet.

\section{Metode Analisis Data}

Analisis data merupakan salah satu kegiatan penelitian berupa proses penyusunan dan pengolahan data guna menafsirkan data yang telah diperoleh. Dalam penelitian ini, penulis menggunakan metode analisis kuantitatif untuk mendapatkan data penelitian.

Dalam melakukan analisis terhadap data yang dikumpulkan untuk mencapai suatu kesimpulan, penelitian ini menggunakan analisis Regresi Berganda dengan pengolahan data menggunakan SPSS 16.

\section{HASIL DAN PEMBAHASAN}

Berdasarkan hasil dan pengolahan datakuesioner menggunakan program SPSS 16 yang telah dilakukan, maka pembahasan terhadap hipotesis penelitian ini adalah :

\section{A. Pengaruh Kualitas Produk (X1), Terhadap Keputusan Pembelian Konsumen ( $\mathrm{Y}$ )}

Diperoleh bahwa nilai t-hitung untuk variabel adalah sebesar 3,674 yang nilai nya lebih kecil dari t-tabel ( $d f=n-k-1=120-3-1, \alpha=5 \%=1,66)$ maka $\mathrm{H} 1$ diterima karena nilai t-hitung lebih besar dari t-tabel $(3,674<1,66)$ dan $\mathrm{HO}$ ditolak, jadi dapat disimpulkan bahwa Kualitas Produk berpengaruh positif dan signifikan terhadap Keputusan Pembelian Konsumen, atau bisa dikatakan hipotesis penelitian kedua diterima.

\section{B. Pengaruh Promosi Penjualan (X2), Terhadap Keputusan Pembelian Konsumen ( $\mathrm{Y}$ )}

Diperoleh bahwa nilai t-hitung untuk variabel adalah sebesar 2,526 yang nilai nya lebih besar dari $t$-tabel $(d f=n-k-1=120-3-1, \alpha=5 \%=1,66)$ maka $H 1$ diterima karena nilai t-hitung lebih besar dari t-tabel $(2,526<1,66)$ dan $\mathrm{H} 0$ ditolak, jadi dapat disimpulkan bahwa Promosi Penjualan berpengaruh positif dan 
signifikan terhadap Keputusan Pembelian Konsumen, atau bisa dikatakan hipotesis penelitian ketiga diterima.

\section{Pengaruh Lokasi Gerai (X3), Terhadap Keputusan Pembelian Konsumen}

(Y)

Diperoleh bahwa nilai t-hitung untuk variabel adalah sebesar 0,65 yang nilai nya lebih besar dari t-tabel $(\mathrm{df}=\mathrm{n}-\mathrm{k}-1=120-3-1, \alpha=5 \%=1,66)$ maka $\mathrm{HO}$ diterima karena nilai t-hitung lebih besar dari t-tabel $(0,65>1,66)$ dan $\mathrm{H} 1$ ditolak, jadi dapat disimpulkan bahwa Lokasi Gerai tidak berpengaruh positif dan signifikan terhadap Keputusan Pembelian Konsumen, atau bisa dikatakan hipotesis penelitian keempat ditolak.

\section{KESIMPULAN}

Hasil penelitian mengenai "Pengaruh Kualitas Produk, Promosi penjualan dan Lokasi Gerai Terhadap Keputusan Pembelian Tas Eiger di Kota Bogor", dapat dibuat beberapa kesimpulan sebagai berikut :

1. Kualitas Produk berpengaruh secara positif dan signifikan terhadap Keputusan Pembelian Konsumen dengan nilai koefisien regresi sebesar 3,674 dan memiliki nilai signifikan sebesar 0,000.

2. Promosi Penjualan berpengaruh secara positif dan signifikan terhadap Keputusan Pembelian Konsumen dengan nilai koefisien regresi sebesar 2,526 dan memiliki nilai signifikan sebesar 0,000.

3. Lokasi Gerai tidak berpengaruh secara positif dan signifikan terhadap Keputusan Pembelian Konsumen dengan nilai koefisien regresi sebesar 0,65 dan memiliki nilai signifikan sebesar 0,000.

4. Pengaruh Kualitas Produk, Promosi Penjualan dan Lokasi Gerai, secara bersama-sama memiliki pengaruh yang positif dan signifikan terhadap Keputusan Pembelian Konsumen, berdasarkan F hitung sebesar 11,283 dan lebih besar dibandingkan $F$ tabel 2,68 dengan nilai signifikansi sebesar 0,000. Artinya semakin baik Kualitas Produk, Promosi Penjualan dan Lokasi Gerai maka Keputusan Pembelian Konsumen semakin tinggi 


\section{SARAN}

1. Berdasarkan indeks jawaban responden pada variabel Kualitas Produk dapat diketahui bahwa skor rata-rata paling kecil terdapat pada pernyataan 8 yang merupakan pernyataan yang mengukur tentang tingkat kerusakan yang dimiliki tas Eiger mudah untuk diperbaiki, berdasarkan hasiltanggapan responden pernyataan 8 memiliki skor ratarata 3,24 dapat disimpulkan sedang, hal ini berarti rata-rata responden sudah merasakan kesan ketertarikan yang signifikan pada tas merek Eiger,meskipun begitu manajemen PT Eigerindo Multi Produk Industri tetap harus lebih memberikan perhatian terhadap variabel Kualitas Produk agar PT Eigerindo Multi Produk Industri bisa menjadi lebih baik lagi untuk kedepan nya, oleh karena itu pihak manajemen PT Eigerindo Multi Produk Industri perlu selalu melakukan evaluasi terkait pengembangan Kualitas Produk yang dirasakan konsumen, yang harus dilakukan peningkatan kinerja dari manajemen untuk pengembangan terhadap kualitas tas Eiger.

2. Berdasarkan indeks jawaban responden pada variabel Promosi Penjualan dapat diketahui bahwa skor rata-rata paling kecil terdapat pada pernyataan 5 yang merupakan pernyataan yang mengukur bagaimana keterkaitan produk tas Eiger dalam memberikan promosi kupon gratis pada konsumen yang berlangganan dan penilaian responden pada tas merek Eiger, berdasarkan hasil tanggapan responden pernyataan 5 memiliki skor rata-rata 3,64 dapat disimpulkan sedang, hal ini berarti rata-rata responden sudah merasakan Promosi Penjualan yang signifikan pada tas merek Eiger, meskipun begitu manajemen PT Eigerindo Multi Produk Industri tetap harus lebih memberikan perhatian terhadap variabel Promosi Penjualan agar tas merek Eiger bisa menjadi lebih baik lagi untuk kedepan nya, oleh karena itu pihak manajemen PT Eigerindo Multi Produk Industri perlu selalu melakukan evaluasi terkait penekanan Promosi Penjualan yang dirasakan konsumen, yang harus dilakukan peningkatan kinerja dari manajemen untuk menekankan Promosi Penjualan tersebut.

3. Berdasarkan indeks jawaban responden pada variabel Lokasi Gerai dapat diketahui bahwa skor rata-rata paling kecil terdapat pada 
pernyataan 6 yang merupakan pernyataan yang mengukur mengenai ukuran bangunan dan keluasan didalam gerai Eiger, berdasarkan hasil tanggapan responden pernyataan 6 memiliki skor rata-rata yang sama yaitu 3,35 dapat disimpulkan sedang, hal ini berarti rata-rata responden sudah merasakan kesan yang baik pada tas merek Eiger, meskipun begitu manajemen PT Eigerindo Multi Produk Industri tetap harus lebih memberikan perhatian terhadap variabel Lokasi Gerai agar PT Eigerindo Multi Produk Industri bisa menjadi lebih baik lagi untuk kedepan nya, oleh karena itu pihak manajemen PT Eigerindo Multi Produk Industriperlu selalu melakukan evaluasi terkait penekanan Harga yang dirasakan konsumen, yang harus dilakukan peningkatan kinerja dari manajemen untuk mengembangkan Lokasi Gerai tersebut.

4. Untuk penelitian selanjutnya diharapkan Peneliti mampu untuk dapat melakukan penelitian dalam cakupan yang lebih luas, sehingga mendapatkan hasil yang lebih baik, populasi dan sampel lebih banyak sehingga dapat menghasilkan hasil yang lebih maksimal.

\section{DAFTAR PUSTAKA}

Buchari Alma, 2008. Manajemen Pemasaran Dan Pemasaran Jasa, Bandung:Alfabeta.

Berkowitz, et al., 2012, Manajemen Pemasaran Modern, Liberty : Yogyakarta.

Kotler, Keller, 2013. Manajemen Pemasaran, Jilid 1, Edisi 13 Jakarta: Erlangga.

Meliana, S., \& Setiawan, B. (2013). Pengaruh Kualitas Pelayanan dan Kepercayaan Konsumen Terhadap Keputusan Pembelian. IImiah Manajemen Kesatuan, 1, 247-254.

Setiawan, B., \& Rabuani, C. (2019). Pengaruh Iklan dan Endorser terhadap Brand Awareness serta Dampaknya pada Keputusan Pembelian. Jurnal Riset, 1(1), 001-015. https://doi.org/10.35212/277621

Setiawan, B. (2018, April 7). A Critical Review of the Business Agility Literature in the Advancement of Information and Communication Technology. https://doi.org/10.31227/osf.io/x4kwj

Setiawan, B. (2015). Teknik Praktis Analisis Data Penelitian Sosial dan Bisnis dengan SPSS. Penerbit Andi, Yogyakarta. 
Setiawan, B. (2010). Strategi Pengembangan Usaha Kerajinan Bambu di Wilayah Kampung Pajeleran Sukahati Kecamatan Cibinong Kabupaten Bogor. Jurnal Manajemen dan Organisasi, 1(2), 135-147.

Swastha dan Irawan, 2009, Manajemen Pemasaran Modern. Yogyakarta: Liberty.

Sugiyono. 2010. Metode Penelitian Bisnis. Bandung

Sujarweni, V Wiratna. 2015. Metode Penelitian Bisnis Dan Ekonomi. Yogyakarta PT. Pustaka Baru Press

Sumaatmadja, Nursid. 2009. Studi geografi : suatu pendekatan dan analisa. Keruangan. Bandung : Alumni.

Tjiptono Fandy, 2008. Strategi Pemasaran. Edisi 3, ANDI: Yogyakarta. 